2013

\title{
The Dialectic of Stare Decisis Doctrine
}

Colin Starger

University of Baltimore School of Law, cstarger@ubalt.edu

Follow this and additional works at: http://scholarworks.law.ubalt.edu/all_fac

Part of the Legal History Commons, and the Supreme Court of the United States Commons

\section{Recommended Citation}

The Dialectic of Stare Decisis Doctrine, in Precedent in the United States Supreme Court (Christopher J. Peters, ed., 2013)

This Book Chapter is brought to you for free and open access by the Faculty Scholarship at ScholarWorks@University of Baltimore School of Law. It has been accepted for inclusion in All Faculty Scholarship by an authorized administrator of ScholarWorks@University of Baltimore School of Law. For more information, please contact snolan@ubalt.edu. 


\section{The Dialectic of Stare Decisis Doctrine}

Colin P. Starger

University of Baltimore Law School 


\title{
The Dialectic of Stare Decisis Doctrine
}

\author{
Colin Starger - 4/15/13
}

In the United States Supreme Court, the concept of stare decisis operates as both metadoctrine and doctrine. On the one hand, stare decisis functions as a generally applicable presumption in favor of adherence to precedent. This presumption is metadoctrinal because it provides a generic argument against overruling that applies independently of the substantive context of any given case. On the other hand, when the Court considers overruling a particularly controversial precedent, it usually weighs the constraining force of stare decisis by invoking factors and tests announced in its own prior caselaw. In other words, the Court has precedent about when to follow its precedent. This "precedent about precedent" seems doctrinal in the conventional sense - it is the Court's doctrine of stare decisis.

The existence of a stand-alone stare decisis doctrine in the Supreme Court was hardly inevitable. The Constitution does not mention precedent at all and thus provides no textual guidance about when stare decisis should be respected. Perhaps predictably, the Court historically decided overruling questions on a case-by-case basis without any reference to "precedent about precedent." Prior to the early twentieth century, if Court opinions discussed stare decisis at all, they typically referred to the concept as a "maxim" or "principle" that abstractly weighed in favor of following past decisions. ${ }^{1}$ Though the maxim commanded respect, its authority and meaning were derived from common law tradition rather than from prior Court pronouncements.

Not so today. Consider the Court's controversial 2010 Citizens United decision. ${ }^{2}$ In Citizens United, a sharply divided Court struck down a federal law barring certain corporate electioneering expenditures on the grounds that the law violated the First Amendment. While most remember Citizens United as opening the door to unlimited political spending by "super PACs," the case also featured a fierce debate about the majority's overruling of two existing First Amendment cases. ${ }^{3}$ Writing for the majority, Justice Kennedy cited the Court's 2009 decision in Montejo $v$. Louisiana for the proposition that the "relevant factors in deciding whether to adhere to the principle of stare decisis include the antiquity of the precedent, the reliance interests at stake, and [ ] whether the decision was well reasoned." 4 In dissent, Justice Stevens countered that whether a precedent was "well reasoned" was a "merits argument" not entitled to "weight in the stare decisis calculus." Quoting 1992's Planned Parenthood v. Casey, Stevens insisted that "[a]

\footnotetext{
${ }^{1}$ See, e.g., Pennsylvania v. Coxe, 4 U.S. 170, 192 (1800) (argument of counsel) ("Stare decisis [] is a maxim to be held forever sacred [] on questions of property."); Cook v. Moffat, 46 U.S. 295, 309 ("So far [] as the present case is concerned, the court do not think it necessary or prudent to depart from the safe maxim of stare decisis."); Bienville Water Supply Co. v. City of Mobile, 186 U.S. 212, 217 (1902) (“[W]e may, on the principle of stare decisis, rightfully examine and consider the decision in the former case as affecting the consideration of this.").

${ }^{2}$ Citizens United v. Federal Election Comm'n, 558 U.S. 310, 130 S.Ct. 876 (2010).

${ }^{3}$ See Citizens United, 130 S.Ct. at 913 (overruling Austin v. Michigan Chamber of Commerce, 494 U.S. 652 (1990)); id. (overruling McConnell v. Federal Election Comm’n, 540 U.S. 93 (2003)).

${ }^{4}$ Id. at 912 (quoting Montejo v. Louisiana, 129 S.Ct. 2079, 2088-89 (2009)).

${ }^{5}$ Id. at 939 (Stevens, J., dissenting).
} 
decision to overrule should rest on some special reason above and beyond the belief that a prior case was wrongly decided." 6

Critically, this argument between Kennedy and Stevens in Citizens United assumed a doctrinal form. The authority of Montejo was pitted against that of Casey to support conflicting positions on whether stare decisis requires adherence to precedent despite disagreement with prior reasoning. As it happens, the cited opinions in Montejo and Casey themselves cite back to different earlier cases to support their competing interpretations about the appropriate test for overruling precedent. The clash in Citizens United over stare decisis thus reflects an ongoing dialectic in Court discourse that is distinct from any First Amendment controversy. Instead of a generic maxim associated with common-law tradition, the concept of stare decisis appears to have become a contested doctrine.

How did this happen? How did stare decisis transform from a common law maxim into a doctrinal dialectic? The goal of this Chapter is to answer this essentially historical question and then analyze its implications for our current understanding of precedent on the Unites States Supreme Court. After undertaking a historical analysis that charts the evolution of stare decisis on the Court from maxim to contested doctrine, the Chapter seeks to shed light on how much stare decisis doctrine actually constrains decision-making or affects outcomes in directly substantive territories of the Court's constitutional and statutory jurisprudence. Put another way, this Chapter maps the dialectic of stare decisis doctrine in order to assess whether the Court's "precedent about precedent" has any genuine precedential value.

The Chapter proceeds in three parts.

Part I begins the inquiry by reviewing the early era of the Court's precedent jurisprudence, which extends from the Founding up until Justice Brandeis' landmark dissent in 1932's Burnet v. Coronado Oil \& Gas Co. ${ }^{7}$ This part shows how, prior to Brandeis' dissent, abstract stare decisis discussions played almost no doctrinal or analytical role in Court debates about overruling precedent. However, Brandeis forever changed this discourse. His Coronado Oil dissent catalogued the Court's actual overruling practices in such a powerful manner that his attendant stare decisis analysis immediately assumed canonical authority. Overruling debates after Brandeis appealed to Court doctrine on stare decisis.

Part II analyzes the evolution of Court discourse from Coronado Oil until Citizens United. Through the use of graphical "opinion maps," this part illustrates how modern stare decisis doctrine became a dialectic. The dialectic pits competing lines of opinions against each other. The competing opinion lines diverge on whether stare decisis requires adherence to precedent in face of disagreement with prior reasoning. Although both lines ultimately trace back to Brandeis' Coronado Oil dissent, this part demonstrates how the contemporary conflict emerged from a key debate between Chief Justice Rehnquist and Justice Thurgood Marshall in 1991's Payne v. Tennessee. The Payne debate serves as the blueprint for the Court's modern dialectic of stare decisis doctrine.

\footnotetext{
${ }^{6}$ Id. at 938 (quoting Planned Parenthood of Southeastern Pa. v. Casey, 505 U.S. 833, 864 (1992)).

${ }^{7}$ Burnet v. Coronado Oil \& Gas Co., 285 U.S. 393, 405 (1932) (Brandeis, J., dissenting).
} 
With the history mapped out, Part III takes a critical look at the competing claims in the contemporary stare decisis dialectic. By analyzing the arguments pressed by both sides in context, this final part considers whether the Court's stare decisis doctrine has any genuine precedential value. It concludes that even though the doctrine's actual constraint on Supreme Court decision-making is minimal, it retains real political and rhetorical significance.

\section{I - Early Era Stare Decisis Jurisprudence and the Impact of Brandeis}

Article III of the Constitution vests the "judicial Power of the United States" in the Supreme Court and in inferior courts established by Congress. Beyond describing the subjects of the power's jurisdiction, Article III does not articulate principles governing the proper exercise of this judicial power. Similarly, though Article VI establishes the Constitution as the supreme law of the land, and though various Amendments guarantee important substantive and procedural rights, no constitutional provision explains how to interpret or apply this supreme law and its guaranteed rights. The Constitution, in short, provides no rules of judicial adjudication.

The absence of constitutionally mandated adjudicatory rules never posed a problem for the Supreme Court. From the start, the Court was able to go about interpreting the Constitution without difficulty. This is because the Constitution did not displace all the law that came before it - the new republic inherited the common law and its associated traditions. Just as common law doctrines regarding property and contract persisted, so too continued common law traditions governing interpretation of doctrine.

Of course, the Court never formally announced all the adjudicatory rules or metadoctrinal principles it adopted from the common law. Rather, the rules and principles guiding Court deliberations were organically revealed in its published opinions starting in 1791. Careful analysis of these opinions indicates that the common law maxim stare decisis et non quieta movere ("to stand by things decided, and not to disturb settled points") played a role in Court adjudication from the founding. However, this analysis also shows that early era stare decisis discourse differed significantly from modern stare decisis doctrine.

For purposes of this inquiry, the early era of the Court's stare decisis jurisprudence extends from 1791 until 1916. The era begins in the year the Court issued its first written opinion and ends when Louis Brandeis became an Associate Justice. ${ }^{8}$ During this 125 -year period, the phrase "stare decisis" appears in only 40 published decisions. ${ }^{9}$ Looking closer, stare decisis was invoked in 22 majority opinions, 15 dissenting opinions, one concurring opinion and five reported arguments of counsel. ${ }^{10}$ The vast majority of early these stare decisis references involved no analysis of the concept. Instead, invocation of the maxim usually served a simple

\footnotetext{
${ }^{8}$ See West v. Barnes, 2 U.S. 401 (1791) (first published opinion by the Court); Hutchinson Ice Cream Co. v. Iowa, 242 U.S. 153 (1916) (first Brandeis opinion for the Court).

${ }^{9}$ This number is based on a simple keyword search for "stare decisis" in Westlaw's comprehensive Supreme Court database. This search produces 45 separate decisions published before 1916. However, I eliminated five of these decisions because the phrase did not appear in an actual opinion or summary of counsel's argument.

${ }^{10}$ These numbers are based upon an examination of the decisions discussed in supra note 9 . Although modern Supreme Court reports do not separately summarize the arguments of counsel, this practice is evident in early era reporting as late as 1870. See Legal Tender Cases, 79 U.S. 457, 459-528 (1870) (69 pages devoted to reporting arguments of counsel).
} 
rhetorical function in arguments about following precedent. A brief survey of these early decisions uncovers the typical usage.

The very first reported reference to stare decisis in the United States Reports is actually both typical and atypical. In 1800's Pennsylvania v. Coxe, the Court considered an action seeking to force the Secretary of the Land Office to issue patents to the Holland Company for lands that had been warranted to the company by act of the Pennsylvania General Assembly. ${ }^{11}$ In his argument, counsel for the Holland Company stated: "Stare decisis, is a maxim to be held forever sacred, on questions of property; and, in the present instance, applies with particular force, as the rule was given by the state herself, through the medium of her officers." 12

This reference is typical in its use of stare decisis to support a generic appeal to follow existing law and also in its suggestion that precedent applies with special force on questions of property. However, the reference is atypical because it urges adherence to a non-Supreme Court precedent (an act of the Pennsylvania legislature). Early-era appeals to stare decisis normally concerned fidelity to Court precedent alone. Stare decisis is not usually understood to require the Court to follow law set down by inferior or foreign courts, much less by a state legislature.

Although the earliest references to stare decisis in the United States Reports surfaced in arguments of counsel, the concept soon found rhetorical use in majority and dissenting opinions alike. Thus, in 1831's Ex Parte Crane, Justice Baldwin dissented from the majority's conclusion that the Supreme Court had a previously unrecognized mandamus power. ${ }^{13}$ After surveying the "embryo system of American jurisprudence," Baldwin concluded that "this court is called on to assert a power, which in the forty-two years of its existence it has never exercised" and so announced "I must follow my own judgment, and dissent in the threshold: obsta principiis stare decisis." 14

Where Baldwin deployed stare decisis to summarize his argument about absence of precedent, others used the phrase to summarily justify fidelity to existing precedent. 1847's Cook v. Moffat supplies a representative example. In that case, the Court affirmed a line of cases regarding discharge of contracts under state insolvent laws. ${ }^{15}$ Justice Grier concluded his majority opinion by observing "in order to meet the views of the learned counsel for the plaintiff in error, we should be compelled to overrule every case heretofore decided... [but] the court do not think it necessary or prudent to depart from the safe maxim of stare decisis." 16

Not all early-era discussions of stare decisis advocated following the maxim in such a conclusory fashion. Indeed, some opinions that argued for overruling precedent featured more extensive analysis about the Court's obligation to its own prior decisions. The oldest exemplar of this genre is Chief Justice Taney's majority opinion 1850's The Genesee Chief. The case held that federal admiralty jurisdiction extended to certain navigable lakes and rivers, which

\footnotetext{
${ }^{11}$ See Pennsylvania v. Coxe, 4 U.S. 170 (1800).

${ }^{12}$ Id. at 192.

${ }^{13}$ See generally Ex Parte Crane, 30 U.S. 190 (1831).

${ }^{14}$ See id. at 221, 222 (Baldwin, J., dissenting).

${ }^{15}$ Cook v. Moffat, 46 U.S. 295 (1847).

${ }^{16}$ Id. at 309.
} 
effectively overruled an 1825 decision called The Thomas Jefferson. ${ }^{17}$ Acknowledging this change in the law, Taney first explained that The Thomas Jefferson "did not decide any question of property, or lay down any rule by which the right of property should be determined." $18 \mathrm{He}$ then argued that when Court precedent concerns property rights, "stare decisis is the safe and established rule of judicial policy, and should always be adhered to." 19 However, since The Thomas Jefferson concerned jurisdiction only, and "as we are convinced that the former decision was founded in error [that will] produce serious public as well as private inconvenience and loss," Taney concluded the case could be overruled. ${ }^{20}$

Chief Justice Taney's suggestion that stare decisis had less force on jurisdictional questions was implicitly contested in a fascinating case decided just three years later -1853 's Marshall v. Baltimore \& O. R. Co. ${ }^{21}$ The plaintiff in the case, a shady character named Marshall, had allegedly contracted with the Baltimore and Ohio Railroad Company to peddle influence in the Virginia legislature in order to obtain passage of a law favorable to the corporation. The law passed, but the corporation refused to pay. Marshall then audaciously sued the railway company in federal court. After losing below, Marshall appealed to the Supreme Court, where he faced numerous objections - including to the very existence of federal diversity jurisdiction. ${ }^{22}$ Marshall, a citizen of Virginia, claimed diversity existed because the corporation was a "citizen" of Maryland.

On the jurisdictional question, the Court held for Marshall. Citing Louisville Railroad v. Letson, an 1844 decision that recognized corporate citizenship for diversity purposes, Justice Grier's majority opinion explained:

[Letson] has, for the space of ten years, been received by the bar as a final settlement of the [jurisdictional] questions which have so frequently arisen under this clause of the Constitution... There are no cases, where an adherence to the maxim of "stare decisis" is so absolutely necessary to the peace of society, as those which affect retroactively the jurisdiction of the courts, for this reason alone, even if the court were now of the opinion that the principles affirmed in the case... were not founded on right reason, we should not be justified in overruling them. ${ }^{23}$

Here Grier articulated a very robust vision of stare decisis. He insisted that ten years of reliance on Letson rendered the correctness of the precedent's reasoning wholly irrelevant, effectively insulating the decision from overruling.

Although the majority ultimately ruled against Marshall - holding his contract void on public policy grounds - Grier's jurisdictional and stare decisis analyses did not go unchallenged.

\footnotetext{
${ }^{17}$ See The Genesee Chief, 53 U.S. 443, 458-59 (1851) (overruling The Thomas Jefferson, 23 U.S. 428 (1825)).

${ }^{18}$ Id. at 458 .

${ }^{19}$ Id.

${ }^{20}$ Id. at 459.

${ }^{21}$ Marshall v. Baltimore \& O. R. Co., 57 U.S. 314 (1853).

${ }^{22}$ Diversity jurisdiction refers to federal courts' exercise of authority over cases involving parties who are citizens of different states and an amount in controversy greater than a statutory minimum. See 28 U.S.C. $\S 1332$.

${ }^{23}$ Id. at 325-26 (citing Louisville, C. \& C. R. Co. v. Letson, 43 U.S. 497 (1844)) (emphasis added).
} 
Indeed, Justice Daniel vociferously dissented. Refusing to comment on "the settlement of the discreditable controversy," Daniel wryly suggested that the parties "settle their dispute by some standard which is cognate to the transaction in which they have been engaged." ${ }^{24} \mathrm{He}$ then frontally attacked the Court doctrine that recognized corporations as citizens. After detailing his critique, Daniel expressed his incredulity at the majority's appeal to stare decisis. He argued that the doctrine creating "this new class of citizen corporations" was "strictly a new creation, an alien and an intruder" that could "trace its being no farther back than [Letson]." ${ }^{25}$ Daniel then opined:

[Stare decisis] is doubtless a wholesome rule of decision when derived from legitimate and competent authority... but, like every other rule, must be fruitful of ill when it shall be wrested to the suppression of reason or duty, or to the arbitrary maintenance of injustice, of palpable error, or of absurdity. ${ }^{26}$

Seeing Letson's doctrine as absurd, unjust, and devoid of constitutional reason, Daniel argued the precedent should not be saved by the rule of stare decisis. By appealing to the soundness of a precedent's reasoning in overruling decisions, Daniel thus voiced a weak view of stare decisis.

The debate in Marshall between Justices Grier and Daniel marks the first time in Supreme Court discourse that majority and dissent explicitly clashed over the interpretation and application of stare decisis. Remarkably enough, this conflict over the rights of corporations and role of stare decisis preceded Citizens United by 157 years. Just as in Citizens United, the competing justices in Marshall staked out opposite positions on whether stare decisis requires adherence to precedent despite disagreement with prior reasoning. However, unlike Kennedy and Stevens in Citizens United, neither Grier nor Daniel appealed to prior Court precedent to support his view of stare decisis. This failure to cite stare decisis precedent seems a real missed opportunity for Justice Daniel in particular. Recalling Chief Justice Taney's analysis explored above, Daniel could have invoked The Genesee Chief for the proposition that Court precedents about jurisdiction have little stare decisis value. Invoking The Genesee Chief might well have given Daniel's argument in favor of overruling Letson more authority. ${ }^{27}$

Of course, hindsight is always twenty-twenty. Critiquing Daniel's failure to cite The Genesee Chief now is probably unfair given the discursive norms of the time. Indeed, out of the 40 published opinions referencing stare decisis in the early era, only one relied on prior authority to justify an abstract argument about overruling precedent. This single exception to the rule Justice White's dissent in 1903's Kean v. Calumet Canal \& Improvement Co. - is thus entirely unrepresentative of the early era. ${ }^{28}$ Far more representative are the opinions discussed and analyzed above - Pennsylvania v. Coxe, Ex Parte Crane, The Genesee Chief and Marshall $v$.

${ }^{24}$ Id. at 338 (Daniel, J., dissenting).

${ }^{25}$ Id. at 343.

${ }^{26} \mathrm{Id}$.

${ }^{27}$ Of course, Grier might have responded that The Genesee Chief concerned the expansion of federal jurisdiction rather than contraction. The merits of this distinction are irrelevant; the point is that Grier and Daniel did not debate it.

${ }^{28}$ See Kean v. Calumet Canal \&Improvement Co., 190 U.S. 452, 505-07 (1903) (White, J., dissenting). Compared to Brandeis' subsequent use of "precedent about precedent," Justice White's argument for overruling was neither successful nor influential in Court discourse. 
Baltimore \& O. R. Co. Whether these cases mentioned stare decisis briefly or discussed the concept in some detail, these cases all show that stare decisis was originally understood as a common-law maxim rather than the subject of Court doctrine. Prior to twentieth century, Supreme Court justices simply did not frame arguments about the propriety of overruling precedent by reference to prior Court decisions.

\section{Louis Brandeis changed all that.}

In a series of dissenting opinions culminating in 1932's Burnet v. Coronado Oil \& Gas Co., Justice Brandeis developed an analysis of stare decisis based upon a rigorous empirical study of the Court's actual overruling practices. Brandeis so carefully mined and categorized the Court's own "precedent about precedent" in his opinions that his attendant framework for the proper application of stare decisis itself assumed canonical authority. In both content and form, Brandeis' Coronado Oil dissent established new discursive standards that effectively gave birth to the Court's modern stare decisis doctrine. Given its importance to the Court's current jurisprudence, a careful reading of Coronado Oil is in order.

The substantive context giving rise to Brandeis' famous dissent concerned the federal government's attempts to levy taxes against the Coronado Oil \& Gas Company. This private corporation derived all of its income from oil fields that it leased from the State of Oklahoma; it claimed exemption from federal income taxation on the theory its lease made it an instrumentality of the State. Five justices agreed with the corporation. In his opinion for majority, Justice McReynolds singled out a 1922 precedent called Gillespie v. Oklahoma and argued that "the present claim of exemption cannot be distinguished from the one presented in [Gillespie]." 29 Because the "opinion in Gillespie [] has often been referred to as the expression of an accepted principle," McReynolds concluded that "we adhere to the rule there approved." 30 Though he did not use the phrase, McReynolds clearly took refuge in the principle of stare decisis.

In dissent, Justice Brandeis minced no words starting with his opening lines: "Under the rule of Gillespie [], vast private incomes are being given immunity from state and federal taxation... that case was wrongly decided and should now be frankly overruled." 31 From this direct framing of the issue, Brandeis launched immediately into his stare decisis analysis. His first sentence is oft-repeated: "Stare decisis is not, like the rule of res judicata, a universal inexorable command." 32 Brandeis then concisely articulated the general arguments for and against the application of stare decisis. He began:

Stare decisis is usually the wise policy, because in most matters it is more important that the applicable rule of law be settled than that it be settled right...

\footnotetext{
${ }^{29}$ Burnet v. Coronado Oil \& Gas Co., 285 U.S. 393,398 (1932) (citing Gillespie v. Oklahoma, 257 U.S. 501 (1922)).

${ }^{30}$ Id. at 399-400, 398.

${ }^{31}$ Id. at 405 (Brandeis, J., dissenting).

${ }^{32}$ Id. Res judicata ("a thing adjudicated") refers to the doctrine otherwise known as "claim preclusion," which bars the same parties from litigating a second lawsuit on the same claim. Brandeis actually cribbed his "universal inexorable command" phrase from a dissent he had penned eight years earlier. Compare Washington v. W.C. Dawson \& Co., 264 U.S. 219, 238 (1924) (Brandeis, J., dissenting). Like any sensible and productive writer, Brandeis borrowed freely from his own prior work.
} 
This is commonly true even where the error is a matter of serious concern, provided correction can be had by legislation. ${ }^{33}$

According to Brandeis then, stability in the law is the overriding justification for the presumption in favor of following precedent. He sees stability in judicial decision-making as so critical that the burden to correct "bad" precedents should ordinarily fall on legislatures. However, that is not the whole story:

But in cases involving the Federal Constitution, where correction through legislative action is practically impossible, this court has often overruled its earlier decisions. The court bows to the lessons of experience and the force of better reasoning, recognizing that the process of trial and error, so fruitful in the physical sciences, is appropriate also in the judicial function. ${ }^{34}$

Per Brandeis, the effectively unreviewable nature of the Court's constitutional decision-making demands an exception to the general presumption in favor of stare decisis. He therefore concludes that the Court should not hesitate to overrule precedents that contradict experience or good reason.

While sharp and succinctly put, Brandeis' abstract analysis is not what gives the opinion its real rhetorical force. Rather, his footnotes are what jump off the page and seize the reader's attention. Brandeis drops three footnotes in the short paragraph just quoted - and those notes occupy two full pages of the United States Reports. The first footnote follows the sentence suggesting that stare decisis is especially wise policy when Court "error[s]" can be corrected by legislation. Dryly observing that the Court has "occasionally overruled its earlier decisions although correction might have been secured by legislation," this footnote catalogs over a dozen non-Constitutional precedents and the subsequent cases that overruled them. ${ }^{35}$ The second footnote lists nearly thirty overruled or abrogated Constitutional precedents as well as the cases that effected the change. ${ }^{36}$ The third footnote features quotes from Chief Justice Taney as well as Justices Miller and Field that all approve of reviewing precedent in light of forceful reasoning or the test of experience. ${ }^{37}$

Cumulatively, these footnotes demonstrated to an empirical certainty that the Court had historically treated stare decisis as a discretionary principle. Brandeis cited authority en masse to prove that overruling was a realistic option and one frequently taken by the Court. Having established these general premises, Brandeis then brought home his specific argument for overruling Gillespie. Adherence to stare decisis is not advisable, he argued, when the challenged precedent was based on factual determinations "influenced by prevailing views as to economic or social policy which have since been abandoned." ${ }^{38}$ Gillespie suffered from this flaw since it

\footnotetext{
${ }^{33} I d$. at 406. Brandeis lifted the "more important that a rule of law be settled, than that it be settled right" from a dissent he wrote five years earlier. Compare DiSanto v. Pennsylvania, 273 U.S. 34, 42 (1927) (Brandeis, J., dissenting).

${ }^{34} I d$. at $406-08$.

${ }^{35} \mathrm{Id}$. at $406, \mathrm{n} .1$.

${ }^{36} I d$. at 407, n. 2.

${ }^{37} I d$. at 408, n. 3.

${ }^{38} I d$. at 410, 412.
} 
rested on an essentially factual judgment that taxing a private company's lease profits would "interfere substantially with the functions of state government." 39 Given that better reasoning suggested that Gillespie was wrong about this, Brandeis concluded the case should be overruled.

History shows that Brandeis' argument succeeded brilliantly. On the federal income tax question, the Court did indeed frankly overrule Gillespie six short years after the Coronado Oil majority declined to do so. ${ }^{40}$ More than this, Brandeis's influence over the Court's stare decisis jurisprudence was profound. Thus, in three separate opinions written between 1936 and 1944, Justice (and then Chief Justice) Stone specifically cited to Brandeis' Coronado Oil dissent and its extraordinary footnotes to support propositions about the Court's ability to overrule its constitutional precedents. ${ }^{41}$ By 1949, Justice Rutledge had similarly referred to "the trenchant discussion by Mr. Justice Brandeis of the lesser impact of stare decisis in the realm of constitutional construction" and highlighted "the instances in which this court has overruled prior constitutional determinations [] catalogued in [Coronado Oil]." "42 Brandeis' dissent soon assumed canonical authority.

Brandeis dramatically impacted both the substance and form of the Court's stare decisis jurisprudence. Substantively, Brandeis' analysis about the proper conditions for adhering to precedent still resonates. Justices to this day quote or paraphrase his most famous aphorisms like "stare decisis is not an inexorable command" or "it is more important that the law be settled than that it be settled right." Formally, Brandeis made it de rigueur for justices to cite Court authority when discussing stare decisis. After Coronado Oil, no Court opinion has ever again described stare decisis as a maxim. Abstract debates about overruling precedent instead proceed by reference to the Court's own prior pronouncements on the topic. In short, stare decisis transformed from common-law maxim to Supreme Court doctrine.

\section{II - Mapping the Dialectic of Stare Decisis Doctrine}

Contemporary stare decisis doctrine may owe its existence to Brandeis, but it also exhibits a dialectical form. As demonstrated by the debate in Citizens United, the discourse now has two distinct tests for when the Court can rightly overrule its own precedents. The first test advocates what I call a "weak" conception of stare decisis that sanctions overruling if a challenged precedent suffers from "bad reasoning." The second test promotes what I call a "strong" version of stare decisis - one that requires a "special justification" for overruling beyond mere belief that the challenged precedent was "wrongly decided." Given the existence of two competing stare decisis tests, it seems unlikely that Coronado Oil alone - a single source gave rise to contemporary doctrine.

So how did these weak and strong conceptions of stare decisis emerge in modern discourse? This part answers this question by tracing back to their doctrinal roots the competing

\footnotetext{
${ }^{39}$ Id. at 412 .

${ }^{40}$ See Helvering v. Mountain Producers Corp., 303 U.S. 376, 387 (1938) (overruling Gillespie).

${ }^{41}$ See St. Joseph Stock Yards Co. v. United States, 298 U.S. 38, 93 (1936) (Stone, J., concurring); Connecticut General Life Ins. Co. v. Johnson, 303 U.S. 77, 85 \& n. 10 (1938); United States v. South-Eastern Underwriters Ass'n, 322 U.S. 533, 579 (1944) (Stone, C.J., dissenting).

${ }^{42}$ See National Mut. Ins. Co. of District of Columbia v. Tidewater Transfer Co., 337 U.S. 582,618 n. 11 (1949) (Rutledge, J., concurring).
} 
stare decisis tests advocated by Justices Kennedy and Stevens in Citizens United. This process of doctrinal tracing is visually represented through a series of "opinion maps" that illustrate the relationships between the competing opinions in the weak and strong stare decisis traditions. The opinion maps initially confirm that both traditions share common ancestry in Brandeis' Coronado Oil dissent. However, analysis of the doctrinal history also reveals that the stare decisis debate in Citizens United effectively carries on an argument first engaged between Chief Justice Rehnquist and Justice Thurgood Marshall in 1991's Payne v. Tennessee. It is the debate in Payne that provides the real blueprint for the Court's modern dialectic of stare decisis doctrine.

Citizens United currently stands as the latest major installment of the Court's ongoing argument over stare decisis. The stare decisis debate in the case stemmed from the majority's controversial decision to expand the First Amendment rights of corporations. To reach this result, the majority had to overrule a 1990 precedent called Austin v. Michigan Chamber of Commerce. ${ }^{43}$ Writing for the majority, Justice Kennedy concluded that overruling Austin was justified after applying a weak stare decisis test. In dissent, Justice Stevens relied upon a strong stare decisis test when he protested that the Court's doctrine actually required adherence to Austin. Since Kennedy and Stevens invoked competing opinions to establish their competing tests, it makes sense to look back at those opinions, as well as the opinions they in turn relied on, to uncover the roots of the dialectic between strong and weak schools.

Before applying this citation-tracing method to the stare decisis tests advocated by Kennedy and Stevens in Citizens United, it bears emphasis that neither jurist used the adjectives "weak" or "strong" to describe their competing tests. Rather, I have introduced these terms to distinguish between conflicting doctrinal formulations of the proper inquiry the Court should use when deciding whether to overrule one of its precedents. The weak test is so-called because it effectively grants stare decisis less constraining power to prevent overruling than the so-called strong test. Once again, I want to be clear that the actual doctrinal formulations do not use the phrases like "constraining power." Instead, as shown below, the linguistic difference turns on the role of "reasoning" or "justification."

Consider first the origins of the weak stare decisis test. Directly quoting 2009's Montejo v. Louisiana, Kennedy posited in his Citizens United majority opinion that the "relevant factors in deciding whether to adhere to the principle of stare decisis include the antiquity of the precedent, the reliance interests at stake, and of course, whether the decision was well reasoned." 44 (The emphasis on the soundness of the precedent case's reasoning signals that Kennedy is adopting the weak test.) As it happens, Justice Scalia wrote the majority opinion in Montejo - and he, in turn, relied on at least two earlier opinions to authorize this formulation of the appropriate stare decisis test. Those earlier opinions again invoked prior cases, and so on. This chain of opinions that effectively constitute the weak tradition is represented in Figure 1 below.

\footnotetext{
${ }^{43}$ See Citizens United, 130 S.Ct. at 913 (overruling Austin v. Michigan Chamber of Commerce, 494 U.S. 652 (1990)). The Court notably also overruled another more recent precedent. See id. (overruling McConnell v. Federal Election Com'n, 540 U.S. 93 (2003)).

${ }^{44}$ Id. at 912 (quoting Montejo v. Louisiana, 129 S.Ct. 2079, 2088-89 (2009)) (emphasis supplied).
} 
Since this is the first opinion map presented, a brief introduction to the schema is in order. ${ }^{45}$ Each triangle on the map represents a Court opinion; the case name appears above the opinion and its author's name appears below. The $\mathrm{X}$-axis indicates the year the opinion case was decided. The Y-axis shows the number of votes the opinion received on the Court - how many of the Court's nine Justices joined in the opinion. Under this schema, all points above the dashed line are thus majority opinions. Solid arrows connecting opinions indicate that the latter opinion directly cited the earlier one. The resulting picture is of continuous lines of authority that stand for a particular proposition in Court discourse.

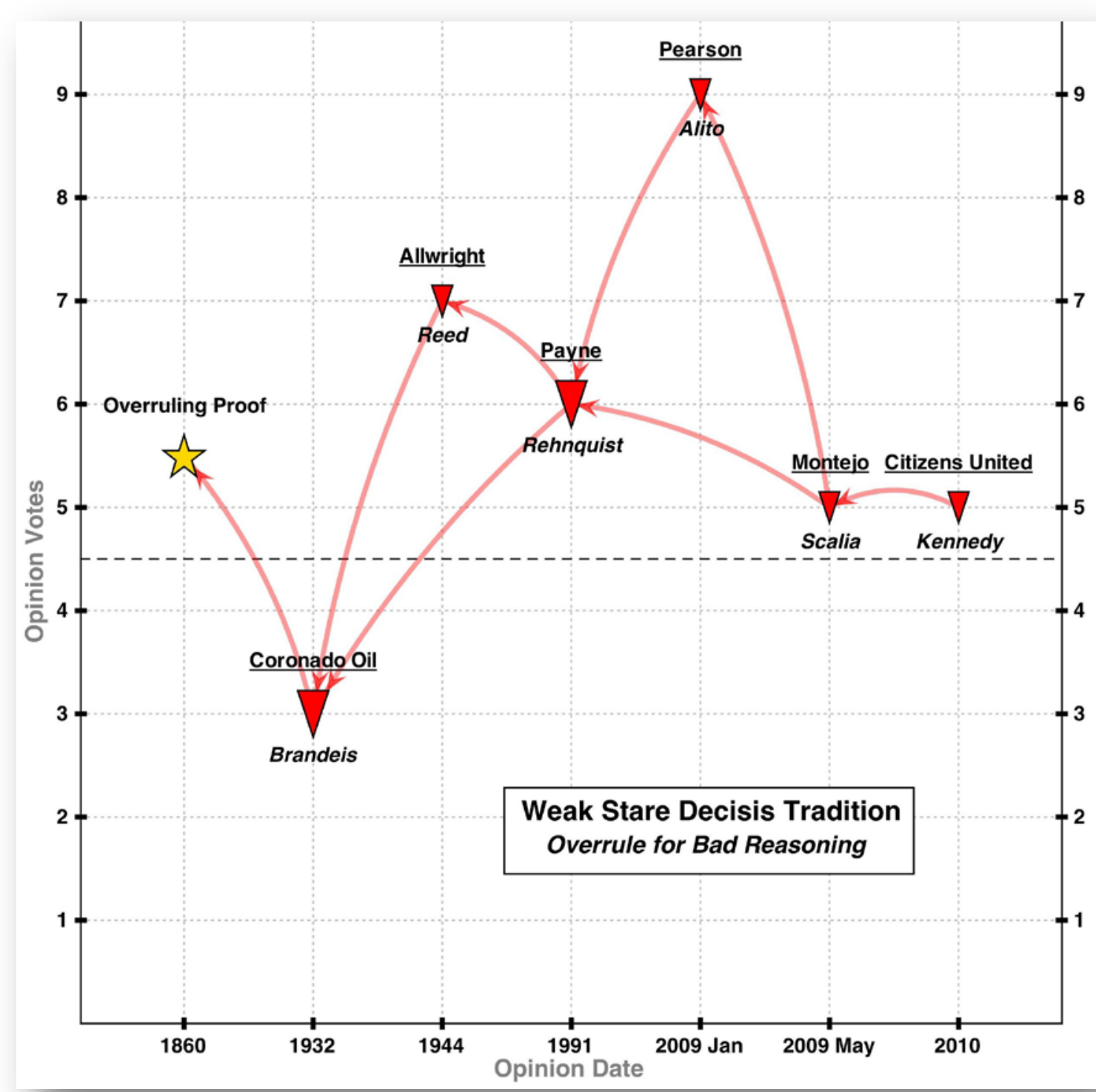

Figure 1

\footnotetext{
${ }^{45}$ For a thorough discussion of the theory animating this doctrinal mapping schema, see Colin Starger, Exile on Main Street: Competing Traditions and Due Process Dissent, 95 MARQ. L. REV. 1253 (2012); Colin Starger, Expanding Stare Decisis: The Role of Precedent in the Unfolding Dialectic of Brady v. Maryland, 46 LOY. L.A. L. REV. (2013).
} 
Figure 1 represents the connections between opinions endorsing the proposition that stare decisis permits overruling a precedent case that suffers from "bad reasoning." While no opinion in this tradition has ever precisely explained what constitutes a "well reasoned" or "badly reasoned" decision, specific consideration of the challenged precedent's quality of reasoning is the distinctive characteristic of the weak stare decisis test. The map thus shows that Kennedy's assertion that a relevant factor in overruling is whether a precedent is "well reasoned" traces all the way back to Brandeis' Coronado Oil dissent. The exact chain of citation connects, in reverse-chronological order, the following opinions: Citizens United v. Federal Election Commission (Justice Kennedy for the Court, 2010); ${ }^{46}$ Montejo v. Louisiana (Justice Scalia for the Court, 2009); ${ }^{47}$ Pearson v. Callahan (Justice Alito for the Court, 2009); ${ }^{48}$ Payne v. Tennessee (Chief Justice Rehnquist for the Court, 1991); ${ }^{49}$ Smith v. Allwright (Justice Reed for the Court, 1944); ${ }^{50}$ and Burnet v. Coronado Oil \& Gas Co. (Justice Brandeis dissenting, 1932). ${ }^{51}$

Although the earliest opinion in Figure 1 is Coronado Oil, a further arrow extends back to a star labeled "overruling proof." This is intended to represent the proof set forth in the footnotes of Brandeis' famous dissent. As discussed in the previous part, these footnotes definitively showed that - at least prior to 1932 - the Court had overruled its constitutional precedents when dissatisfied with their underlying reasoning. The form and content of Brandeis' proof exerted great influence over the subsequent discourse. In 1944, for example, Justice Reed argued in Allwright that "when convinced of former error, this Court has never felt constrained to follow precedent." 52 To prove this proposition, Reed first cited to Brandeis' footnotes and then dropped his own footnote that documented a dozen new overrulings that had occurred since 1932. ${ }^{53}$ Then in 1991, Chief Justice Rehnquist employed the same technique in Payne when he carefully cataloged 33 constitutional decisions that had been overruled in the prior 20 years. ${ }^{54}$ The empirical reality of the Court's overruling practice thus stands as the ultimate backing for the weak stare decisis tradition.

What about the competing strong tradition? To uncover the doctrinal origins of the strong stare decisis tradition, it makes sense to once again start with Citizens United and work backwards. In his Citizens United dissent, Stevens argued that stare decisis demands "significant

\footnotetext{
${ }^{46}$ Citizens United v. Federal Election Com'n, 130 S.Ct. 876 (2010). Citizens United was a 5-4 decision. Justice Kennedy wrote the majority opinion. Chief Justice Roberts wrote a separate concurrence, which was joined by Justice Alito. Justice Stevens' dissent received 4 votes.

${ }^{47}$ Montejo v. Louisiana, 556 U.S. 778 (2009). Montejo was a 5-4 decision. Justice Scalia wrote the majority opinion. Justice Alito wrote a separate concurrence. Justice Stevens' dissent received 4 votes.

${ }^{48}$ Pearson v. Callahan, 555 U.S. 223 (2009). Pearson was a 9-0 decision. Justice Alito wrote the majority opinion.

${ }^{49}$ Payne v. Tennessee, 501 U.S. 808 (1991). Payne was a 6-3 decision. Chief Justice Rehnquist wrote the majority opinion. Justice Scalia wrote a separate concurrence that received three votes. Justice Marshall's dissent received 3 votes.

${ }^{50}$ Smith v. Allwright, 321 U.S. 649 (1944). Allwright was a 8-1 decision. Justice Reed wrote the majority opinion which received 7 votes. Justice Frankfurter concurred in result only. Justice Roberts wrote a solo dissent.

${ }^{51}$ Burnet v. Coronado Oil \& Gas Co., 285 U.S. 393 (Brandeis, J., dissenting). Coronado Oil was a 5-4 decision. Justice McReynolds wrote the majority opinion. Justice Stone's dissent received 4 votes. Justice Brandeis' dissent received 3 votes.

${ }_{53}^{52}$ Allwright, 321 U.S. at 665.

${ }^{53} \mathrm{Id}$. at $665, \mathrm{n} .10$.

${ }^{54}$ See Payne, 321 U.S. at 828, n. 1.
} 
justification beyond the preferences of five Justices [] for overruling settled doctrine." ${ }^{55}$ Directly quoting 1992's Planned Parenthood of Southeastern Pa. v. Casey, Stevens elaborated that "a decision to overrule should rest on some special reason over and above the belief that a prior case was wrongly decided." ${ }^{56}$ Casey, of course, rejected a constitutional challenge to the right to an abortion and adhered to Roe v. Wade primarily on stare decisis grounds. To support its view that in absence of "special justification" stare decisis requires adherence to precedent, the joint opinion in Casey inevitably cited earlier decisions.

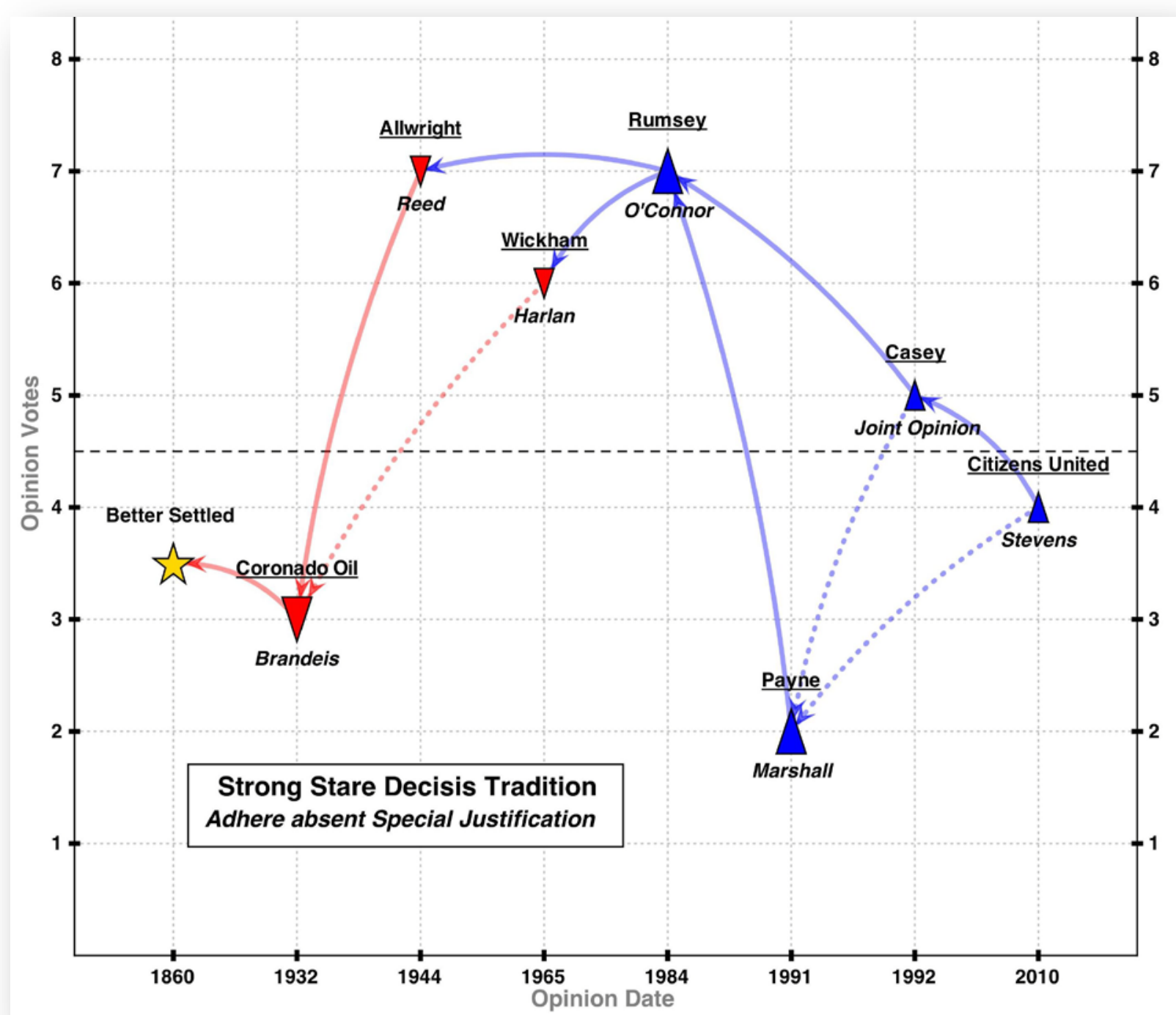

Figure 2

Figure 2 represents the connections between opinions theoretically endorsing the strong stare decisis proposition that overruling Court precedent is prohibited absent "special justification." At the outset, it is apparent that this map is more complicated than that presented

${ }^{55}$ Citizens United, 130 S.Ct. at 938 (Stevens, J., dissenting).

${ }^{56}$ Id. at 938 (quoting Planned Parenthood of Southeastern Pa. v. Casey, 505 U.S. 833, 864 (1992)). 
in Figure 1.This reflects the rather complex origins of the "special justification" formulation of the stare decisis test. To understand the map's depiction of this origin story, further explanation is required. Note how the map uses both blue and red triangles to depict opinions. The blue triangles point upward to indicate that they are opinions that affirmed a challenged precedent case (or, if written in dissent, advocated affirming the precedent). By contrast, the red triangles point downward to indicate that they are opinions that overruled a challenged precedent (or advocated overruling) ${ }^{57}$ Thus, although the chain of citation extends from Stevens' dissent in Citizens United back to Brandeis' dissent in Coronado Oil, the map shows that Justice O'Connor's 1984 opinion in Rumsey is actually the earliest opinion in the strong stare decisis tradition that adhered to a challenged precedent.

This reveals a key difference between the strong and weak traditions. While all the opinions in the weak stare decisis line ultimately advocated overruling a challenged precedent, all of the opinions in the strong stare decisis line were not similarly uniform in advocating adherence to a challenged precedent. Before exploring this apparent contradiction, a formal listing of the opinions in Figure 2 is in order. In reverse chronological order, they are: Citizens United (Justice Stevens dissenting, 2010) $;{ }^{58}$ Planned Parenthood of Southeastern Pa. v. Casey (Joint plurality opinion by O'Connor, Kennedy, and Souter, 1992); ${ }^{59}$ Payne (Justice Marshall dissenting, 1991); ${ }^{60}$ Rumsey v. Arizona (Justice O'Connor for the Court, 1984) $;{ }^{61}$ Swift \& Co. v. Wickham (Justice Harlan for the Court, 1965); ${ }^{62}$ Allwright (Justice Reed for the Court, 1944); ${ }^{63}$ and Coronado Oil (Justice Brandeis dissenting, 1932). ${ }^{64}$

As noted, the apparent contradiction presented by Figure 2 is that strong stare decisis tradition traces its origins to three opinions that did not advocate adhering to precedent Wickham, Allwright, and Coronado Oil. This contradiction is not all together surprising given the tensions in Brandeis' foundational Coronado Oil dissent. Though the dissent clearly bowed to the force of better reasoning in constitutional decision-making, Brandeis also famously described stare decisis as the default wise policy because "in most matters, it is more important that the applicable law be settled than that it be settled right."

On its own, this aphorism is not inconsistent with the strong stare decisis notion that a decision to overrule should rest on more than "the belief that a prior case was wrongly decided."

\footnotetext{
${ }^{57}$ This second map also introduces dotted arrows to connect opinions despite the lack of a formal citation relationship. I use dotted arrows to assert that the opinions are nonetheless connected and form part of the same tradition. Specific justifications for these dotted arrows are provided below when discussing the particular opinions.

${ }^{58}$ See supra note 46.

${ }^{59}$ Planned Parenthood of Southeastern Pa. v. Casey, 505 U.S. 833 (1992). Casey was a 5-4 decision. No single opinion commanded a majority. Justices O'Connor, Kennedy, and Souter authority a joint plurality opinion. Justices Stevens and Blackmun wrote separate solo opinions concurring in part. Chief Justice Rehnquist and Justice Scalia both wrote dissents that each received four votes.

${ }^{60}$ See supra note 49.

${ }^{61}$ Rumsey v. Arizona, 467 U.S. 203 (1984). Rumsey was a 7-2 decision. Justice O’Connor wrote the majority opinion. Chief Justice Rehnquist wrote a dissent that received two votes.

${ }^{62}$ Swift \& Co. v. Wickham, 382 U.S. 111 (1965). Wickham was a 6-3 decision. Justice Harlan wrote the majority opinion. Justice Douglas dissented and his opinion received 3 votes.

${ }^{63}$ See supra note 50.

${ }^{64}$ See supra note 51.
} 
Figure 2 represents the connection between this aspect of Coronado Oil and the strong stare decisis tradition by extending an arrow back from the dissent to a star labeled "Better Settled."

Clearly, Brandeis's polite nod to the wisdom of stare decisis does not adequately explain the origins of the strong tradition embraced by Stevens in Citizens United. A more complete explanation requires a closer analysis of the doctrine. The focus should be etymological. This is because one hallmark phrase is repeated enough in the doctrine that it fairly stands as shorthand for the entire strong stare decisis tradition - "special justification." In the roots of this phrase lie the origins of the strong tradition's most consistent theme.

The basic etymological inquiry is simple enough. As scholars have previously acknowledged, Justice O'Connor introduced the phrase "special justification" into Court discourse in 1984's Rumsey. ${ }^{65}$ Writing for the majority, O'Connor's opinion had granted relief to a criminal defendant via a relatively straightforward application of a 1981 double-jeopardy precedent. Seeking to avoid this result, the State of Arizona had in its briefing urged the Court to overrule the precedent. In response, O'Connor wrote: "We decline the invitation. Although adherence to precedent is not rigidly required in constitutional cases, any departure from the doctrine of stare decisis demands special justification." 66

This simple sentence is the sole source of the Court's current special justification language, but it provoked no stare decisis debate at the time. Indeed, the phrase did not assume any real significance in the discourse until the doctrine-defining debate between Chief Justice Rehnquist and Justice Marshall eight years later in Payne. It was really Marshall's dissent in Payne that provided the first unambiguous articulation of the strong stare decisis test. A review of O'Connor's citations in Rumsey confirms that the earlier doctrine essentially adopted a weak stare decisis perspective.

For her "special justification" proposition, O'Connor directly cited two cases - Wickham and Allwright. As noted, both of those cases overruled rather than affirmed prior precedent. Yet O'Connor apparently relied on language in, rather than the results of, these decisions to support the special justification proposition. In Wickham, the Court overruled a three-year-old precedent penned by Justice Frankfurter. Only tacitly admitting the stare decisis implications of this move, Harlan wrote in his majority opinion:

The overruling of a six-to-two decision of such recent vintage, which was concurred in by two members of the majority in the present case and the opinion in support of which was written by an acknowledged expert in the field of federal jurisdiction, demands full explication of our reasons. ${ }^{67}$

Harlan then explicated his reasons - since it had been decided, the challenged precedent had sown confusion in the lower courts and proved unworkable. Though the unworkability of a

\footnotetext{
65 See Emery G. Lee III, Overruling Rhetoric: The Court's New Approach to Stare Decisis in Constitutional Cases, 33 U. TOL. L. REV. 581 (2001) (noting origin of "special justification" in Rumsey).

${ }^{66}$ Rumsey, 467 U.S. at 212.

${ }^{67}$ Wickham, 383 U.S. at 116 (overruling Kesler v. Dep't of Public Safety, 369 U.S. 153 (1962)) (internal footnotes and citations omitted).
} 
precedent certainly counts as a special justification for overruling under current doctrine, it bears emphasis that Harlan did not frame his Wickham discussion as a general reflection on stare decisis. Instead, his "full explication of our reasons" phrase was inextricably linked to the enormity of overruling a three-year-old Frankfurter opinion.

O'Connor's "special justification" formulation is even more tenuously supported by her citation to Allwright. Decided in 1944, Allwright held that the Fifteenth Amendment prohibited racial discrimination in primary elections of political parties, thereby overruling a unanimous 1935 precedent that had permitted such discrimination. The only language in Justice Reed's majority opinion that even arguably promoted stare decisis was this: "In reaching this [overruling] conclusion, we are not unmindful of the desirability of continuity of decision in constitutional questions. ${ }^{68}$ However, Reed then strenuously insisted on the propriety of overruling precedent when convinced of former error. This discussion more squarely locates Allwright in the weak stare decisis tradition - an orientation confirmed by Allwright's depiction in Figure 1 above. Given this, O'Connor's citation to Allwright is indeed puzzling - perhaps she regarded the correction of a rank racial injustice as exemplifying a special justification.

In any event, it is clear that neither Wickham nor Allwright support a strong view of stare decisis. This mattered little at the time since Rumsey did not provoke a stare decisis debate. O'Connor's argument for adhering to precedent was not challenged abstractly. The reality is that in Rumsey, she did not use the phrase "special justification" in a rhetorically or doctrinally significant sense. The phrase only assumed such significance in Payne. Because of its centrality to the modern dialectic, Payne deserves a more detailed analysis.

The specific legal controversy in Payne turned on whether the Eighth Amendment permitted jury consideration of victim impact evidence. Previous majorities had prohibited victim impact evidence in cases called Booth and Gathers. Writing for a six-justice majority, Rehnquist overruled these cases. In so doing, the Chief Justice advanced two critical propositions about stare decisis doctrine. First, he argued that "considerations in favor of stare decisis are at their acme in cases involving property and contract rights where reliance interests are involved" and that "the opposite is true in cases such as the present one involving procedural and evidentiary rules." 69 Second, Rehnquist suggested that Booth and Gathers were ripe for overruling because they had been "decided by the narrowest of margins, over spirited dissents challenging the basic underpinnings of those decisions."

In dissent, Justice Marshall loudly objected to Rehnquist's articulation of the stare decisis inquiry. Marshall specifically accused Rehnquist of creating a "radical new exception to the doctrine of stare decisis" by suggesting that the Court could freely "discard any principle of constitutional liberty which was recognized or reaffirmed over the dissenting votes of four Justices and with which five or more Justices now disagree." ${ }^{71}$ Rejecting Rehnquist's weak test, Marshall posited that

\footnotetext{
${ }^{68}$ Allwright, 321 U.S. at 665 (overruling Grovey v. Townsend, 295 U.S. 45 (1935)).

${ }^{69}$ See Payne, 501 U.S. at 828.

${ }^{70}$ Id. at 829 (overruling Booth v. Maryland, 482 U.S. 496 (1987) and South Carolina v. Gathers, 490 U.S. 805 (1989)).

${ }^{71}$ Id. at 845 (Marshall, J., dissenting) (emphasis in original).
} 
[t]he overruling of one of this Court's precedents ought to be a matter of great moment and consequence... Consequently, this Court has never departed from precedent without 'special justification., 72

For this last proposition, Marshall naturally quoted Rumsey.

Marshall then elaborated on what he believed constituted special justifications. In the main, legitimate justifications were major factual or legal developments that undermined a challenged precedent's essential rationale. Turning to the precedents at hand, Marshall argued that no legal or factual developments justified overruling Booth and Gathers. He boldly suggested that the only change of note since those cases were handed down was in the Court's own personnel. Rather than provide the special justification required by stare decisis, this new majority had simply - and illegitimately - elevated the dissents from Booth and Gathers into the law of the land.

The razor-sharp vehemence of Marshall's dissent attracted the attention of the other justices. In his separate concurrence, Justice Scalia suggested that Marshall acted hypocritically by "demand[ing] of us some "special justification.", "73 Justice Souter, who also concurred, took a less personal tack and argued that the Court did indeed possess "special justification" for overruling Booth and Gathers. ${ }^{74}$ The substantive merits of these competing claims are not relevant for this inquiry. What is relevant is that "special justification" suddenly took center stage. Although the phrase had only been politely echoed in two cases since Rumsey, it now became the linguistic axis around which the stare decisis debate turned. ${ }^{75}$ And it has played a lead role in the discourse ever since.

While this etymological account helps explain the original split between strong and weak stare decisis traditions, the doctrinal history is not yet complete. Grasping the full rhetorical context requires one final look at Marshall's Payne dissent. Confronting Rehnquist's proposition that that stare decisis better protects "cases involving property and contract rights," Marshall warned that majority was "send[ing] a clear signal that essentially all decisions implementing the personal liberties protected by the Bill of Rights and the Fourteenth Amendment are open to reexamination." 76 Furthermore, he argued that

[t]aking into account the majority's additional criterion for overruling - that a case was decided or reaffirmed by a 5-4 margin "over spirited dissents" - the continued vitality of literally scores of decisions must be understood now to depend on nothing more than the proclivities of the individuals who now comprise a majority of this Court. ${ }^{77}$

\footnotetext{
${ }^{72}$ Id. at 848-49 (Marshall, J., dissenting) (quoting Rumsey).

${ }^{73}$ Id. at 834 (Scalia, J., concurring).

${ }^{74}$ Id. at 842 (Souter, J., concurring).

${ }^{75}$ For the only other invocations of Rumsey, see Patterson v. McLean Credit Union, 491 U.S. 164, 172 (1989);

Garcia v. San Antonio Metropolitan Transit Authority, 469 U.S. 528, 557 (Powell, J., dissenting).

${ }^{76}$ Id. at 851 (Marshall, J., dissenting) (emphasis in original).

${ }^{77}$ Id. (emphasis in original).
} 
To dramatize this charge, Marshall proposed a specific list of "endangered precedents" that he suggested might soon be overruled.

The endangered precedents identified by Marshall were all liberal constitutional decisions potentially threatened by the new conservative majority. Marshall presciently included on his list three cases that the Rehnquist Court did in fact overrule within the decade after Payne. ${ }^{78}$ The most prominent decision on his list, however, has so far survived all overruling challenges - Roe v. Wade. Though it remains good law, Marshall's concern for Roe under a weak stare decisis framework was well warranted at the time. After all, Marshall retired from the Court months after Payne and a Republican president (George Bush) appointed a conservative successor (Clarence Thomas). And in the Term immediately following Payne, the Court in fact entertained a very serious challenge to Roe. As it happens, the debate in Payne effectively anticipated perhaps even consciously - the epic stare decisis confrontation in 1992's Casey.

In Casey, the Court reviewed the constitutionality of Pennsylvania laws restricting abortion. Although the Court was explicitly invited to overrule Roe v. Wade, a majority of the Court declined to do so. The majority opinion in Casey probably represents the zenith of the strong stare decisis tradition. This is because the opinion's joint authors (O'Connor, Kennedy, and Souter) explicitly argued that "the force of stare decisis" compelled them to accept Roe despite "the weight of the arguments" for its overruling and even their own "reservations" in reaffirming its central holding. ${ }^{79}$ In other words, the majority hinted that Roe might be "wrong" but argued that stare decisis compelled them to affirm it anyway. Given that Roe is also the Court's most persistently controversial constitutional precedent, the significance of the majority's strong stare decisis stance cannot be overstated.

At the same time, significance should not be confused with originality. The majority in Casey essentially advocated the same strong view of stare decisis that Marshall had championed in Payne. Casey's now-famous test looked to "a series of prudential and pragmatic considerations" to decide whether overruling a precedent was appropriate that included the precedent's workability, reliance interests, related doctrinal development, and changed factual circumstances. ${ }^{80}$ This built upon Marshall's stare decisis considerations and relied on much of the same "precedent about precedent" - including Rumsey - that Marshall had invoked. And yet, the Casey joint authors noticeably failed to cite Marshall's dissent in their opinion. (To reflect this absence of a formal citation relationship, the arrow pointing from Casey to Payne in Figure 2 is dotted).

This failure-to-cite on the part of the Casey majority should not obscure the fact that Marshall's dissent in Payne effectively ushered in a doctrinally distinct strong stare decisis test. Building on Rumsey, Marshall's Payne dissent had dubbed certain considerations as properly part of an overruling inquiry. The Casey majority further developed these same considerations. And like Marshall, the Casey majority did not include the "bad reasoning" of a precedent case as

\footnotetext{
78 See Agostini v. Felton, 521 U.S. 203 (1997) (overruling Aguilar v. Felton, 473 U.S. 402 (1985)); Adarand Constructors v. Pena, 515 U.S. 200 (1995) (overruling Metro Broadcasting v. F.C.C., 497 U.S. 547 (1990)); United States v. Dixon, 509 U.S. 688 (1993) (overruling Grady v. Corbin, 495 U.S. 508 (1990)).

${ }^{79}$ See Casey, 505 U.S. at 853.

${ }^{80}$ Id. at $844-45$.
} 
a relevant stare decisis consideration. Given that Marshall's Payne dissent also loudly signaled stare decisis as an important doctrine to protect particular liberal precedents targeted for overruling - Roe chief among them - it seems evident that the Casey majority very much picked up where Marshall left off.

On the flip side of the dialectic, the Casey dissenters also clearly followed the example set by the Payne majority. In his Casey dissent, Chief Justice Rehnquist thus proclaimed that "authentic principles of stare decisis" require the Court "to bow to the lessons of experience and the force of better reasoning." $"$ Although he did not repeat his claim from Payne that constitutional precedents have less stare decisis value when reached over "spirited dissents," Rehnquist's own spirited dissent in Casey quite obviously embraced the proposition. Meanwhile, Justice Scalia's separate Casey dissent echoed similar core themes. After noting that the joint opinion failed to "squarely contend" that Roe was a correct application of "reasoned judgment," Scalia suggested that a legitimate stare decisis inquiry would ask, "How wrong was the [original] decision on its face?",82

After Payne then, the blueprint for the modern stare decisis dialectic was in place. Strong and weak schools split over whether "authentic principles" of stare decisis properly looked to the "correctness" of a precedent's reasoning in overruling situations. Put another way, the split concerned whether the strength of a prior dissent properly factored into decisions to adhere to a challenged precedent. This split emerged in Payne and continued to play out in Court discourse from Casey to Citizens United.

${ }^{81}$ See Casey, 505 U.S. at 955 (Rehnquist, C.J., dissenting).

${ }^{82}$ Id. at $982-83$ (Scalia, J., dissenting). 


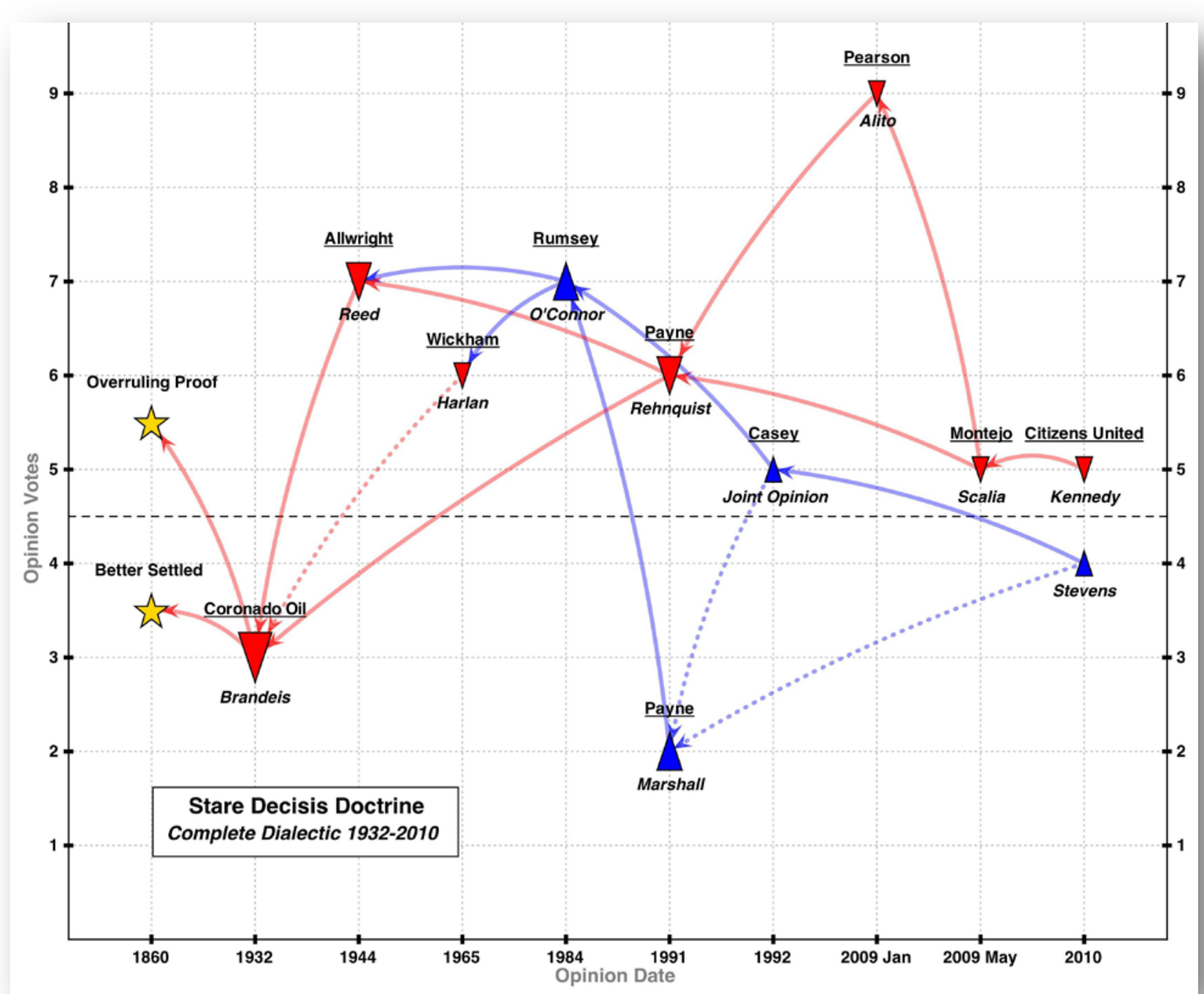

Figure 3

Figure 3 combines Figures 1-2 and to provide a visual summary of the analysis in this part. It bears emphasis, however, that Figure 3 does not purport to represent every opinion in the dialectic of stare decisis doctrine. The map is not the territory. Complete accounts of both the weak and strong stare decisis traditions would undoubtedly include other opinions. ${ }^{83}$ However, the point of the map is not exhaustive detail. Rather, the idea is to represent the most influential and important opinions in the ancestry of the stare decisis debate in Citizens United. To deploy an analogy, Figure 3 is like a constellation map. From a sparkling universe of opinions, it draws

\footnotetext{
${ }^{83}$ Figure 3 does not include all opinions from the weak stare decisis tradition. See, e.g., Casey, 505 U.S. at 955 (Rehnquist, C.J., dissenting); Vasquez v. Hillery, 474 U.S. 254, 269 (Powell, J., dissenting). For other affirmations of the strong stare decisis perspective, see, e.g., Dickerson v. United States, 530 U.S. 428 (2000) (affirming Miranda v. Arizona, 384 U.S. 436 (1966)); Patterson v. McLean Credit Union, 491 U.S. 164 (1989) (affirming Runyon v. McCrary, 427 U.S. 1960 (1976)); Garcia v. San Antonio Metropolitan Transit Authority, 469 U.S. 528,557 (1985) (Powell, J., dissenting)). Dickerson was interesting at the time because Chief Justice Rehnquist wrote the majority opinion. However, its enduring appeal seems limited as no justice cited to it in Citizens United.
} 
lines between the brightest stars in the dialectic. As has been shown, the brightest stars in stare decisis doctrine are Justice Brandeis' Coronado Oil dissent and the competing majority and dissenting opinions in Payne.

\section{III - The Precedential Value of Stare Decisis Doctrine}

With the origins of the strong and weak stare decisis traditions now mapped, this part critically examines the competing claims in the contemporary stare decisis dialectic. Specifically, this part confronts the question - is either side "right" about what the doctrine of stare decisis really requires?

Given that the Court itself ultimately defines the requirements of stare decisis doctrine, the most literal answer to this question is "no." As shown in the previous part, the Court does not speak with one voice on this doctrine. Debate rages on and outcomes are mixed. Since Payne initiated the modern dialectic, both traditions have won victories and suffered losses. Some controversial precedents have been affirmed (like Roe in Casey) while others have been overruled (like Austin in Citizens United). In this sense, stare decisis is like Due Process, Equal Protection, or any other endlessly contested Court doctrine - inherently subjective and utterly immune to "right" interpretation.

However accurate this answer may be as a descriptive matter, it utterly fails to satisfy any normative yearnings. To scratch the normative itch, some judgment - even an imperfect one - is required. Here, judgment is called for on the central question that apparently divides the weak from strong approaches - the degree to which the soundness of a challenged precedent's reasoning is properly part of the stare decisis calculus. Of course, pinning down the precise disagreement between the competing traditions on this question is tricky since neither side speaks in absolutes. Both traditions pay lip service to adhering to precedent when necessary and to overruling precedent when justified. There is ambiguity in how the dueling stare decisis traditions understand "justification" and its relationship to the "reasoning" of precedent decisions.

Given this ambiguity, it makes sense to reframe the inquiry. A useful alternate framework for judgment concerns the competing attitudes toward the reasoning in dissents. After all, the weak stare decisis tradition generally has had no compunction about citing the dissents associated with challenged precedents and frankly adopting the dissent view of the argument when overruling. On the other hand, opinions in the strong stare decisis line have loudly decried the invocation of prior dissents as an illegitimate move incompatible with the rule of law. The competing sides thus seem to have staked out clear and conflicting positions on whether the force of a dissent's reasoning should be given real weight when faced with an overruling decision. The question thus remains: Who has the better argument?

At the outset, the weak tradition's approach of admitting the force of prior dissents' reasoning into the stare decisis calculus seems the presumptive victor. This is because Justice Brandeis clearly embraced this position in Coronado Oil. Since Brandeis effectively transformed stare decisis from a common-law maxim into Court doctrine, his word on the doctrine's content 
demands special deference. Of course, Brandeis did acknowledge - as all inheritors of the weak stare decisis tradition do - that sometimes the law is better settled than settled right. Yet Brandeis notably did not object to later overruling a precedent based on the analysis in a prior dissent. After all, Brandeis was a famously successful dissenter and the force of reasoning in his dissents - Coronado Oil not the least among them - helped change many areas of Court doctrine for the better.

In order t o overcome Brandeis' presumptive authority then, a pointed response to his dissent-embracing analysis is needed. Perhaps the best response here appeals to consistency as a means to preserve Court legitimacy. Though still invoked by the strong tradition, this argument has noble roots that pre-date Brandeis. Consider Smith v. Turner, a case decided in 1849. In the reported argument, counsel for one side asserted that his opponent could only win if the Court overruled an 1832 precedent called Miln. In the course of his argument for stare decisis, he observed:

This court remains, but its members change. Three of the five members who decided in favor of State rights in the case of Miln are gone. Where is Thompson? Where is Baldwin? Where is Barbour, who gave the opinion of the court in that case? Had these judges remained in the seats which they once adorned, this suit would never have been brought. Is it wise thus to invite speculation upon the sad changes which the inevitable doom that awaits us all must produce in this tribunal? If temporary majorities are to give the law of this court, its decisions, which should be as permanent as the republic, will become as fluctuating and mortal as its members. ${ }^{84}$

The idea that Court precedent should not change with every new majority has intuitive appeal. Constitutional law should have more consistency than politics. As Justice Brewer succinctly put it in 1893, "A change in the personnel of a court should not mean a shift in the law." 85

Though advocates for the weak stare decisis tradition would likely agree with Brewer, his observation nonetheless presents a real challenge to Chief Justice Rehnquist's Payne argument that assigned less stare decisis value to precedents obtained by "narrowest of margins, over spirited dissents." By definition, 5-4 decisions are most vulnerable to changes in Court personnel. And new lineups can all-too-easily look to prior dissents to find "better reasoning" to rationalize a change in law actually motivated by ideology.

Major opinions in the weak stare decisis tradition can be plausibly interpreted as ideological overrulings made possible by change in the composition of the Court. In Citizens United, for example, Justice Stevens persuasively argued that the majority overruled Austin simply because it did not "like" Austin and characterized Justice Kennedy's majority's opinion

\footnotetext{
${ }^{84}$ Smith v. Turner, 48 U.S. 283, 364 (1849) (argument of counsel).

${ }^{85}$ Cadawalader v. Wannamaker, 149 U.S. 541, 547 (1893) (Brewer, J., dissenting). The Casey made an essentially similar point almost a century after Brewer's pronouncement when they controversially argued that the Court's legitimacy required it to follow precedent in face of political pressure. See Casey, 505 U.S. at 865-66 ("The Court must take care to speak and act in ways that allow people to accept its decisions on the terms the Court claims for them, as grounded truly in principle, not as compromises with social and political pressures having, as such, no bearing on the principled choices that the Court is obliged to make.")
} 
as "essentially an amalgamation of resuscitated dissents." 86 In fact, Justice Kennedy in Citizens United did favorably cite his very own dissent from Austin and did adopt its reasoning while make his case for overruling. ${ }^{87}$ Similarly, Justice Scalia's majority opinion in Montejo overruled Michigan v. Jackson while citing to Chief Justice Rehnquist's prior Jackson dissent. ${ }^{88}$ Finally, Rehnquist in Payne justified overruling Booth by directly invoking Justice White's Booth dissent. ${ }^{89}$ In all of these cases, a new court lineup looked to prior dissents to rationalize overruling liberal precedents.

Despite this, it would be a mistake to regard the weak stare decisis tradition as a ruse perpetrated by a conservative Court majority. While the post-Payne dialectic has frequently seen the members of the Court's liberal wing appeal to stare decisis to defend older liberal precedents, the pattern is not monolithic. Over time, liberal justices have also frequently advocated overruling based on prior dissents. Indeed, there is a flip-side to the empirical reality of overruling first demonstrated by Brandeis - changes in the composition of the Court have definitely facilitated overruling and justices of all political stripes have taken advantage of this reality.

More than this, individual justices have often taken inconsistent positions on stare decisis doctrine. In Payne, for example, Justice Scalia observed that the "response to Justice Marshall's strenuous defense of the virtues of stare decisis can be found in the writings of Justice Marshall himself." 90 Scalia quoted Marshall's prior observation that stare decisis "is not an imprisonment of reason" and concluded that Marshall really agreed with the proposition that precedents "with plainly inadequate rational support" should be overruled. ${ }^{91}$ In essence, Scalia charged Marshall with adopting the weak approach when he disapproved of the precedent in question and the strong approach when he approved. Meanwhile, though Chief Justice Rehnquist articulated a weak test in Payne, he later took a surprisingly strong stance toward stare decisis in Dickerson $v$. United States - a case that affirmed the notably liberal precedent Miranda v. Arizona. ${ }^{92}$ When Justice Scalia dissented from this stare decisis analysis in Dickerson, Rehnquist subtly pointed to Scalia's own inconsistency by quoting his observation that the fact that a rule has found "wide acceptance in the legal culture... is adequate reason not to overrule it."93

Such examples of inconsistency could be multiplied. However, the basic point is brought home by the fact that Justice Kennedy both wrote the Citizens United majority opinion and was one of the joint opinion authors in Casey. He has thus advocated for and against including an analysis of a challenged precedent's reasoning in the stare decisis calculus. In other words, the

\footnotetext{
${ }^{86}$ Citizens United, 130 S.Ct. at 941-2 (Stevens, J. dissenting).

${ }^{87}$ See also id. at 903 (citing Austin, 494 U.S. at 695 (Kennedy, J., dissenting)).

${ }^{88}$ See Montejo, 129 S.Ct. at 2091 (overruling Michigan v. Jackson, 475 U.S. 625 (1986)). See also id. at 2087 (citing Jackson, 475 U.S. at 1404 (Rehnquist, CJ., dissenting))

${ }^{89}$ See Payne, 501 U.S. at 830 (overruling Booth). See also id. at 825 (citing Booth, 482 U.S. at 517 (White, J., dissenting)).

${ }^{90}$ Payne, 501 U.S. at 833 (Scalia, J., concurring).

${ }^{91}$ Id. (quoting Guardians Assn. v. Civil Service Comm'n of New York City, 463 U.S. 582, 618 (1983) (Marshall, J., dissenting)) (internal citation omitted).

${ }^{92}$ See Dickerson v. United States, 530 U.S. 428, 443 (2000) ("Whether or not we would agree with Miranda's reasoning... in the first instance, the principles of stare decisis weigh heavily against overruling it now.")

${ }^{93}$ Id. (quoting Mitchell v. United States, 526 U.S. 314, 331 (1999) (Scalia, J., dissenting)).
} 
Court's most prominent swing vote has swung wildly on the question of what authentic principles of stare decisis really require.

The widespread inconsistency of justices towards the proper stare decisis test suggests that the Court's "precedent about precedent" itself has little precedential value. From one case to the next, a single justice may analyze overruling questions using different stare decisis tests. Whether the test advocated is weak or strong depends entirely on the result being justified. Strong stare decisis tests -disavowing inquiry into the reasoning of a challenged precedent only ever appear in opinions urging adherence. On the flip side, weak tests that emphasize the force of reasoning in prior dissents only show up in opinions pushing for overruling.

Choosing sides in the debate over stare decisis doctrine is thus ill-advised. Consistency about stare decisis doctrine may sounds like a good rule-of-law idea, but its theoretical value is challenged by the practical bottom line of strong versus weak views of stare decisis. When all is said and done, a weak view of stare decisis authorizes change in doctrine through overruling precedent while a strong view promotes stability by affirming precedent. It seems unfair (if not absurd) to expect any jurist to universally commit ahead of time to always supporting doctrinal change or always supporting doctrinal stability. Sometimes change is good. Sometimes stability is. Context matters immensely.

In the final analysis, stare decisis doctrine is all about context. It is a way of arguing about context - a rhetorical mode for debating first-order Court doctrine. ${ }^{i}$ The competing opinions in the stare decisis dialectic effectively provide a list of ready-made arguments for and against overruling any given precedent. Justices frame their own particular cases for overruling or adhering to precedent by citing to earlier stare decisis discussions. These earlier discussions themselves cite back to even earlier opinions - and so on, in a chain, all the way back to Brandeis' dissent in Coronado Oil. Yet no opinion in the chain can ever stand completely apart from the particular overruling debate that precipitated it.

\footnotetext{
i Aristotle's term for this kind of rhetorical mode was topoi - topics of invention. See generally ARISTOTLE, ON RHETORIC: A ThEORY OF CIVIL Discourse (George A. Kennedy trans., 2d ed. 2007).
} 